THURSDAY, AUGUST 2, 1883

\section{ZOOLOGY AT THE FISHERIES EXHIBITION 1}

\section{II. - Notes on the Vertebrata}

$A T$ the request of the editor of NATURE I have drawn $A$ up this very general report on the Vertebrate animals now exhibited in the natural history sections of the different Courts at the International Fisheries Exhibition. In its compilation I have principally used the notes taken during a month's pretty close attendance at the great piscatorial show in South Kensington, and whilst doing work on the two special juries who had to examine and report on such collections. The space and time conceded preclude entirely anything like a detailed account even of this small portion of the rich and varied exhibit, whilst on the other hand books of reference could not be consulted, and strict nomenclature and systematic arrangement must be partly sacrificed. I shall, however, be content if I succeed in giving a fair general account of this special part of the Fisheries Exhibition, which cannot but interest many of the readers of this periodical to whom the sight of the exhibits themselves, some of very great interest, is not possible. I may also add that to my knowledge one group, that of Birds, wlll be the subject of a special article, to be published shortly in a special journal by one of our leading ornithologists, whilst on the other hand the Cetacea and Pinnipeda will be reported on in the jurors' reports by such distinguished specialists as Prof. Flower and Mr. Clark. I do not know whether any special report on the all-important and largely represented group of Fishes be imminent; I fear not; but as several highly competent ichthyologists have carefully gone over such collections in the Exhibition, I trust that so important a subject will also be laid before the scientific world by a competent reporter.

Before commencing my special task, and before taking the reader through the Vertebrate collections in the International Fisheries Exhibition, for which purpose I consider preferable a zoological to a geographical arrangement, I shall say a few words on the relative importance of the exhibits in this section contributed by different countries. Besides Great Britain and her dependencies, colonies, and possessions, such as the Isle of Man, Heligoland, Canada and Nova Scotia, Newfoundland, British Columbia, the Bahamas, Jamaica, New South Wales, Tasmania, India, Ceylon, and the Straits Settlements, the following foreign countries have contributed to the Fisheries Exhibition: France (not officially), Belgium, the Netherlands, Germany (not officially), Denmark (not officially), Sweden and Norway, Russia, Austria and Hungary, Italy (not officially), Greece, Spain, Switzerland, the United States, Chili, Venezuela, Haiti, China, Japan, Morocco, and Hawaii. Of these, however, nearly a third, viz. France, Germany, Italy, Venezuela, Haiti, Morocco, Japan, and Hawaii have no exhibit to call for our attention, while another third show so little, and that of so small a value that they hardly deserve a passing notice. In the richness, value, and beauty of the Vertebrata exhibited, the foreign countries who compete for the palm are Sweden and the

$$
\text { Continued from p. } 29 \mathrm{r} \text {. }
$$

VOL. XXVIII.-NO. 718
United States of America, far above all the rest in this respect. Great Britain is, on the other hand, singularly defective, none of her great public institutions having taken any part in the competition; this may be partly accounted for by the close proximity of the Buckland Collection of Economic Fishery, adjoining the Fisheries Exhibition, while not much further is the new Natural History Museum in the Cromwell Road, and in this case it is much to be regretted that, at a time when many interested in fish and ichthyology have been attracted from afar by the Fisheries Exhibition, the zoological collections, and more especially the ichthyological ones, are not in a condition to be open to public inspection. However, if Great Britain is, with a single exception, meagrely represented by a few private exhibits in the Vertebrate coliections, it is not so with some of her colonies and possessions, and the Courts occupied by the exhibits of New South Wales, Tasmania, and India are rich in specimens of much interest and great scientific value, while the Dominion of Canada is (in respect of Vertebrates) not far behind them.

The mammals ought in this case to be divided into two groups, those which are fished and those which fish, but I prefer to classify them scientifically rather than popularly. Carnivora mostly belong, when aquatic, to the latter group ; amongst the more abundant are of course the otters, and especially our European kind, of which many specimens are in the British Natural History Gallery; Canada, India, and Chili show specimens of those belonging to their waters, and I was pleased to see in the latter Court fine specimens of my old friend Lutra felina, whose marine habits and agility amongst the kelpbeds of Western Patagonia I witnessed many a time. A few Polar bears are also shown, a very large and fine specimen being in the Russian Court; while Musteline Carnivora of more or less fishing propensities are to be seen amongst the Canadian exhibits. Seals and Otarice form of course a prominent feature in the Exhibition ; foremost in beauty and rarity is no doubt Histriophoca fasciata of the Behring Sea ; the Vega exhibit shows a skull and a rather inflated and dilapidated skin, whilst a magnificent specimen is exhibited by the National Museum, Washington; these are, I believe, the first specimens of that rare mammal ever seen in this country. Some good specimens of Cystophora, Ph. barbata, Ph. gronlandica, Ph. gryphus, are to be seen in the Canadian and Newfoundland exhibits, the latter belonging mostly, I am told, to the Liverpool Museum. Tasmania shows a splendid specimen of Stenorhynchus leptonyx. A large but badly mounted walrus is in the British gallery; but the enormous tusks and cranium and the life-like head of the Pacific species ( $T$. obesus), of whose specific distinctness I should however greatly doubt, call for special attention in the United States department; the very beautiful sketches from life of those unwieldy creatures and of the agile firr seals, drawn by Mr. Elliott in the Pribylov Islands, deserve much praise. The Otaria are represented by a fine group of 0 .ursina $f$ and $q$, the principal source of the sealskin industry, in the United States exhibit, mounted very beautifully indeed; an interesting group of Arctocephalus cinereus is conspicuous in the New South Wales Court, in which is a young specimen of what appears to be a distinet species; Chili has 
several interesting specimens of an Otaria from Juan Fernandez, a true Loboa dospelos, which might be the rare Otaria Philippii.

The strange and uncouth Sirenia are represented by a grand specimen, one of the principal attractions to every naturalist in the entire Exhibition, the nearly complete skeleton of a Rhytina Stelleri, which, with other bones of that most interesting creature is exhibited by Baron Nordenskjöld, one of the many grand results of the Vega expedition; the National Museum of Washington shows a very fine skull of that peculiar, rare, and extinct Sirenoid. Very interesting, and more noticed by the general public, are the two fine mounted specimens, male and female, of the Dugong (Halicore australis), exhibited by the Australian Museum of Sydney.

The Cetacea contribute an important portion of the Vertebrate series, and now and then afford instruction of a novel and rather startling nature; thus the large skeleton of Balcenoptera musculus, covered with luminous paint and set up in the Garảen, shows some remarkable innovations in practical osteology, the natural asymmetry of the skeleton of these creatures is most vividly exaggerated, and we are shown various of the larger paired bones curiously displaced from right to left, and vice versa ; but this is not all, we are told that the whale before us, which by the way was noticed by no less a man than Prof. Flower, when cast upon these shores, is the Greenland Whale (Baicena mysticetus), and the large label thus headed further informs us that it grows to be 75 feet long, swims at the rate of four miles an hour, and possesses a tongue so thick and fleshy, that when the mouth is closed it envelops the upper jaw and all the horny laminæ (baleen plates) along it! Not far off a Berlin dealer in whalebone, Isaac Mann, shows a fine series of baleen plates belonging to several species, but he startles us with the announcement in large letters that "the whale can grow to the length of 200 feet, reach the age of Iooo years, the weight of 20 tons, and is therefore the largest of known fishes." But from the comical and amusing, let us return to more serious and interesting matter; amongst the mounted and entire specimens of Cetacea exhibited, I may mention the large and beautiful Orca gladiator, which forms a prominent feature in the Swedish Court, five young and fœtal porpoises preserved in alcohol, shown by the Gothenburg Museum, and by the Norwegians; the large Beluga in the Canadian exhibit, less life-like, however, than the beautiful cast of the same species shown by the National Museum of the United States; special notice ought to be taken of the rare Orcalla brevirostris from Singapore, in the Straits Settlements exhibit. Skeletons and crania of Cetaceans are more numerous, and for the high scientific value and beauty of specimens exhibited Sweden has in this respect by far the highest rank; the complete skeletons of Orca Eschrichtii, Hyperoodon diodon, and Mesoplodon bidens, will be examined by all zoologists with pleasure and profit, but of more special interest is that of Ziphius Gervaisii. This form, which differs principally from $Z$. cavirostis in the absence of the stony mesorostral bone, and in the size and shape of the two teeth at the apex of the mandible, is probably the female of the latter; whilst examining again that most valuab'e specimen yesterday, I was grieved to find that some unprincipled persoa had abstracted the two teeth, an act of ruthless vandalism or pseudo-scientific kleptomania much to be deplored and condemned.

Birds, of course, figure largely in the British and foreign exhibits; they are more or less aquatic, and may or may not fish or otherwise prove injurious to piscatorial interests. It is to be hoped that the public will not take for granted that every bird displayed in this Exhibition is the fisherman's natural enemy and therefore to be ruthlessly destroyed whenever the opportunity occurs. The dipper, for example, largely repays any occasional injury he may do to the fish spawn by destroying a vast number of insects which habitually feed on it.

Amongst the notable exhibits in this series in the British section is a fine collection of British waterfowl very nicely mounted, shown by T. E. Gunn of Norwich, in which a pair of boodies attacking a wounded widgeon and a pike drawing under water a female mallard are very effective. Mr. Burton's collection of New Zealand waterfowl is also good; and especially worthy of praise is a set of beautiful photographs illustrating bird-life, and more especially the gannets on the Bass Rock and Fern Islands, exhibited by W. P. Carr of Berwick. India, Australia, and the United States show a fair exhibit of their waterfowl, especially Anatidæ, Ardeidæ, Laridæ, Procellaridæ, and Spheniscidæ; but by far the most important exhibits in this class are the rare Arctic birds from the Behring Sea and Alaska in the Swedish and United States Courts. Ornithologists will look with unmitigated delight on the splendid specimens of Eurinorhynchus pygmeus, Colymbus Adamsii, and Rhodostethia Rossi $i$ in the Vega exhibit; and on the magnificent Bernicla canagica, Somateria Fisheri, and Somateria $V$ nigrum, shown both in the Vega and in the National Museum of Washington exhibits; some of these species are seen, I believe, for the first time in this country. A large collection of water-birds of North America, some three hundred species, has besides been sent over in skins by the National Museum of Washington; these, however, have not been exhibited for want of space.

Reptiles contribute a small but not uninteresting series to the Fisheries Exhibition. Amongst the Chelonians the most noticeable are a fine Sphargis coriacea shown by the Australian Museum of Sydney; a large specimen of Chelonia imbricata in the Spanish exhibit from the Philippines; several large turtles, Emy's and Trionyx, in the Indian show, where may also be seen several large crocodiles and a set of snakes, amidst which several species of that most difficult but interesting group the Hydrophidæ, from Karachi. The United States National Museum shows some fine casts of turtles, tortoises, snakes, and lizards, amongst the latter a very fine one of the recently described poisonous lizard of Arizona (Heloderma).

The Amphibia are represented by a complete set of the North American Urodela exhibited in the United States section, while a few Anura are shown by India, and in the Chilian Court may be seen a few more, amongst which is the curious Calyptocephalus Gayi.

Fish naturally contribute the larger portion of the Vertebrata exhibited; in the British gallery may be seen a very great number of the common freshwater game and food fishes exhibited principally by anglers and by angling clubs, mostly mounted dry, and of little or no scientific interest. A small set of freshwater and marine British 
fishes shown by T. E. Gunn and Mr. Carr are noticeable; but of very great interest is the large and nearly complete collection of British fishes exhibited by Dr. Francis Day, they are of special value as being a set of types used by Dr. Day for his work on the fishes of Great Britain and Ireland at present in course of publication. A few interesting Mediterranean species of fish may be seen in the magnificent series of Invertebrata shown by Prof. Anton Dohrn, founder and head of the Zoological Station at Naples ; amongst them are two specimens of Callionymus partenopaus, Gigl., the young of Scymnus lichin, Centrina Salviani, Scyllium stellare, and Myliobatis bovina; a Fierasfer imberbis is shown in the act of getting into a large Holothuria, whilst a specimen of the rare Fierasfer dentatus is of special interest. Good skeletons in alcohol of Ceratodus Forsteri and Cestracion Philippii are exhibited by Mr. Gerard, jun., and some well mounted disarticulated crania of fish are shown by Mr. Moore.

Besides a large set of the admirable cast s of the more conspicuous of their food-fishes, and a splendid series of large photographs of many typical forms of their rich ichthyo-fauna, the United States (National Museum and Fisheries Commission of Washington, both under the able and energetic direction of Prof. Baird) exhibit a most interesting and complete series of type representatives of the freshwater genera of North America; the serics embraces 173 species, amongst which the Ganoids, so well represented in that region, as Amia, Lepidosteus, Spatularia, Scaphirhynchus, and Acipenser deserve special notice. A collection of thirty-eight nominal species of American Salmonoids are also exhibited, and an interesting set they are; these two sets are mostly represented by specimens preserved in alcohol. The National Museum of Washington has also sent over a fine and highly interesting collection of the fishes of Alaska and another of those of the Gulf of Mexico and East Florida, all alcoholic specimens, and not exhibited from want of space. Prof. Brown Goode kindly showed me some of them; the former contains about 100 species, the latter 159. The Alaskan collection is of special interest, and contains many species recently described by Goode, Bean, and other ichthyologists.

In the Canadian Court a numerous series of mounted and alcoholic fish is exhibited, mostly freshwater and well known food-fishes; large specimens of Salmonids, Clupeidæ, Esocidæ, Sturgeons, and Halibuts may be seen, and a curious Lamargus borealis and a very large Orcynus thynnus deserve notice. Some very large Cod may be mentioned in the Newfoundland Court, whilst on the other side of the equator in the new continent, Chili shows a collection of food-fishes, principally marine and from Juan Fernandez, the highly esteemed "Peje Rey" (Atherinichthys) and Heliastes crusma, a large representive of our interesting Mediterranean species, may be recorded.

Sweden shows a magnificent collection of her Salmonidre, large and beautiful specimens wonderfully preserved in alcohol in the finest of glass jars ; an interesting series of types and embryos and larval fish is besides shown by the Gothenburg Museum, but of special interest is the Vega collection from the Arctic seaboard. In the Russian Court a good collection of mounted fish is exhibited, amongst which are to be noticed a large Silurus glanis, a fine Hippoglossus, very fine and large specimens of Lucioperca sandra, an excellent food-fish, which with greater profit than the black bass of America might, I believe, be introduced into British waters; besides a fine set of the various species of sturgeon which abound in Russian waters, and lastly some good enlarged wax models illustrating the development of Acipenser and Petromyzon.

Norway again deserves notice as exhibiring some very fine specimens of rare fist preserved in alcohol or mounted; I may particularly mention Argentina silus, Argyropelecus Olfersii, Sebastes norvegicus, with embryos taken alive from the female, Raja niderosiensis (the type), Scymmus microcephalus, and a fine Opah (Lampris guttatus).

New South Wales (the Australian Museum of Sydney) has one of the very best ichthyological exhibits; besides very beautifully mounted specimens, and very well preserved alcoholic ones, a set of splendid coloured drawings from nature and of natural size, and a large series of photographs of fish are exhibited. Most of the remarkable forms and of the peculiar species of the fish-fauna of Australia are represented. I may specially mention those living fossils Ceratodus and Cestracion, both represented by two species, the former $C$. Forsteri and $C$. miolepis, the latter C.Philippii and C.galeatus; Ceratodus miolepis, exhibited in a dryskin, is the companion specimen to the type. Amongst others of the many interesting species exhibited may be mentioned Galocerdo Rayneri, Carcharodon Rondeletii, Crossorhinus barbatus, Rhinobatis granulosus, Odontaspis taurus, Trygonorhina fasciata, Myliobatis australis, Rhina squatina, Temnodon saltator, the singular Glaucosoma, with its mussel-like opercular appendage, \&c. Some of the freshwater food-fish, as Oligorus, Ctenolabris, and Therapon, are noticeable. A remarkable sun-fish is also exhibited; it differs from our species in shape, in the size and form of the caudal rays, and lastly in being covered with small carinate horny scales, which appear to cover the osseous granulations of the dermis; I am inclined to think that it differs from our $O$. mola, belongs to the southern hemisphere, and if so, might go by the name of Orthragoriscus Ramsayi, as a just acknowledgment to Mr. E. P. Ramsay, Curator of the Australian Museum, who brought it over, and to whose intelligence and activity the splendid exhibit of the New South Wales Court is entirely due.

Tasmania shows a collection of stuffed and alcoholic fishes, some very interesting. A fine Lophotes cepedianus deserves special notice, as also specimens of Galaxias, Retrcpinna Richardsoni, Histiopterus recurvirostris, Phyllopteryx foliatus, and Pristiophorus cirratus.

India exhibits a very large collection of mounted and spirit specimens, from Madras and Bombay principally; worthy of special mention are fine specimens of Histiophorus gladius, H. belone (?), Cybium guttatus, C. Kuhli, Caranx sansun, Megalops indicus, Drepane punctata, Corinemus lysan (so like our Lichia vadigo in appearance), Polyphemus plebejus, Thynnus thunnina, the beautiful Murcena tessellata, Barbustor, Catla Buchanani, Wallago attu, Macrones seenghala, and other peculiar freshwater forms; some interesting Elasmobranchs, as Rhynchobatis djeddensis, Stegostoma tigri, Trygon uarnak, and a Dicerobatis, very like the Mediterranean species. 
Scientifically, however, the most important ichthyological collection exhibite 1 in the Indian department is beyond doubt that shown by Dr. Day-fine specimens in alcohol of several hundred species illustrated in his great work, "The Fishes of In tia." Dr. Day also exhibits a set of his coloured drawings of Indian fish.

The Straits Settlements exhibit a fair sample of the sea-fish of that region, unfortunately unnamed; there are also a few fresh water fishes from Singapore.

China has a rich and interesting collection of fish, and also some very good drawings of them. Unfortunately they also are unnamed. The fishes exhibited are principally in alcohol, and come mostly from Swatow; some are very rare, and others appear to be new to science; amongst those of some interest I may mention: Elacate niger, Rhynchobatis ancylostomus, Zygcena malleus, Cestracion zebra, and some fine species of Pteroplatea, Trygon, Raja. One fish of special importance is Polyodon gladius, from Tchang.

I have now finished, and hope I have been successful in giving a fair general sketch of the Vertebrata shown in the International Fisheries Exhibition; some of the contributions might, no doubt, have been better, but on the whole we may well be content with the opportunity thus given of seeing many good things.

London, July 17

HENRY H. GIGLIOLI

\section{STELLAR NAVIGATION}

Stellar Navigation, with New A, B, and C Tables for Finaing Latitude, Longitude, and Azimuth by Easy Methods. By W. H. Rosser. (Published by Norie and Wilson, 1883.)

' $H$ HERE can be no doubt that star observations, when the horizon is clear and well defined, are the best means by which the position of a ship at sea can be ascertained; as, by altitudes of two or more stars, in suitable positions with regard to the observer, the latitude and longitude can be obtained at the same moment, whereas single observations of heavenly bodies only give one element, and consequently it is not possible to obtain simultaneous observations for botb elements during the day, unless either the moon, Venus, or Jupiter passes the meridian whilst the sun is above the horizon.

It is true that when the azimuth of the sun is changing rapidly the latitude as well as the longitude can be obtained from two sets of observations, taken at a given interval of time, provided the alteration in the position of the ship, during that interval, can be accurately determined; but this supposes a knowledge, not only of the course and distance traversed during the interval, but also of the tidal stream or current affecting the ship, which is usually uncertain.

Any writer or teacher, therefore, who impresses on navigators and students the importance of obtaining star observations is deserving of praise, for it is impossible to take too much precaution in ascertaining the position of a ship ; cloudy or foggy weather may set in at any moment, and an opportunity lost can never be recovered.

Mr. Rosser has in the Nautical Magazine drawn attention to the value of Sumner's method of working out simultaneous observations of two or more stars, and there is little doubt that it is the best, as it is the only method by which results obtained from simultaneous observations of three or more heavenly bodies can be readily combined. It has been for years constantly used by the naval officers employed on surveying service, and in fact by most navigators, though, perhaps, they seldom take observations of more than two stars at the same time. We however prefer three for precisely the same reason we prefer three to two chronometers.

Sumner's method may be thus briefly described. As at a given moment of time each heavenly body is at the zenith at some point on the earth's surface, so at that moment circles may be described on which its altitude will be $80^{\circ}, 70^{\circ}, 60^{\circ}, \& \mathrm{c}$. If then the altitudes of two stars are obtained at the same instant, and the Green wich time be known, the two circles of altitude may be drawn on the earth's surface with the points where the stars are in the zenith as centres, and the point where these circles cut will be the position of the observers. In actual practice it is not necessary to draw the circles, it is merely necessary to be able to draw the arc of a small portion of each circle ; for the position of the observer being generally known to within twenty miles, the arc of the circle of altitude on which he is situated can be readily drawn.

The method of obtaining this arc of altitude formerly practised was to calculate the longitude with two latitudes, using the same two latitudes for each star, which gave four resulting longitudes; then, by plotting these four longitudes on the two parallels, and drawing lines joining the longitudes given by each star, two circles of altitude were obtained, which either cut in a given point, or would do so when produced, which point was the position of the observer.

This method of calculation was however quickly discarded for a more simple one, where one latitude only was used; for as the azimuth of a heavenly body can be readily calculated at the same time as its hour angle, and he azimuth being the bearing of the place where the star is at the zenith from the observer, it is evident that a line drawn at right angles to the azimuth will be the arc of the circle of altitude on which the observer is situated, as practically the arc is, for so short a distance as twenty or thirty miles, a straight line. The two longitudes on one parallel with the azimuth enable the two arcs of altitude to be plotted as before.

The importance of Sumner's method has not as yet been pointed out in any treatise on navigation, principally because since the time of Lieut. Raper, R.N., no treatise has been written by a practical navigator. It is true the method is mentioned in Riddle's "Navigation," and was taught by him many years since, though not in the form now adopted, and we think Mr. Rosser has done good service by urging its importance and the importance of stellar navigation generally. All navigators should in our opinion obtain star observations every night and morning, during twilight, as constant practice will alone render them expert in these observations, and familiar with the positions of the stars.

The extra work entailed by such observations will be amply repaid if, when standing in towards the land, after three or four days' thick weather, a partial break in the clouds enables the expert navigator to secure a couple of star observations which give him his position and enable 